\title{
Hematopoietic Stem Cell Transplantation in Adult Sickle Cell Disease: Problems and Solutions
}

\author{
Erişkin Orak Hücre Hastalı̆̆ında Hematopoietik Kök Hücre \\ Nakli: Problemler ve Çözüm Önerileri
}

\author{
Hakan Özdoğu, Can Boğa \\ Başkent University Faculty of Medicine, Department of Internal Medicine, Division of Hematology, Adana, Turkey
}

\begin{abstract}
:
Sickle cell disease-related organ injuries cannot be prevented despite hydroxyurea use, infection prophylaxis, and supportive therapies. As a consequence, disease-related mortality reaches $14 \%$ in adolescents and young adults. Hematopoietic stem cell transplantation is a unique curative therapeutic approach for sickle cell disease. Myeloablative allogeneic hematopoietic stem cell transplantation is curative for children with sickle cell disease. Current data indicate that long-term disease-free survival is about $90 \%$ and overall survival about $95 \%$ after transplantation. However, it is toxic in adults due to organ injuries. In addition, this curative treatment approach has several limitations, such as difficulties to find donors, transplant-related mortality, graft loss, graft-versus-host disease (GVHD), and infertility. Engraftment effectivity and toxicity for transplantations performed with nonmyeloablative reduced-intensity regimens in adults are being investigated in phase $1 / 2$ trials at many centers. Preliminary data indicate that GVHD could be prevented with transplantations performed using reduced-intensity regimens. It is necessary to develop novel regimens to prevent graft loss and reduce the risk of GVHD.
\end{abstract}

Key Words: Sickle cell disease, Hematopoietic stem cell transplantation, Graft-versus-host disease, Graft rejection, Conditioning

Özet:

Günümüzde hidroksiüre kullanımı, enfeksiyon proflaksisi ve destek tedavileriyle ilgili gelişmelere rağmen orak hücre hastalığına bağlı organ hasarları engellenememekte, adölesan ve genç yetişkinlerde hastalık ilişkili mortalite \%14'lere kadar ulaşmaktadır. Hematopoietik kök hücre transplantasyonu, orak hücre hastalığı tedavisinde tek küratif tedavi yaklaşımıdır. Myeloablatif allojenik hematopietik kök hücre transplantasyonu orak hücre hastalı̆̆ı olan çocuklar için küratiftir. Güncel veriler çocuklarda transplant sonrası uzun dönem hastalıksız yaşam oranının $\% 90$ ve toplam yaşam oranının $\% 95$ civarında olduğunu göstermektedir. Erişkinde hazırlama rejimleri organ hasarları nedeniyle fazla toksiktir. Ayrıca bu küratif tedavi yaklaşımının donör bulma güçlügü, transplant ilişkili mortalite, graft kaybı, graft-versus-host hastalığı (GVHH), infertilite gibi nedenlerle sınırlamaları vardır. Güncel olarak erișkinde toksisitesi azaltılmıș hazırlama rejimleri (myeloablatif olmayan indirgenmiş yoğunluklu) ile yapılan transplantların faz $1 / 2$ çalışmalar ile graft yerleşmesi üzerine etkinliği ve toksisitesi birçok merkez tarafından araştırılmaktadır. Ön veriler, toksisitesi azaltılmış rejimler ile yapılan nakillerde başarılı olarak GVHH'nin engellenebildiğini göstermiştir. Bununla birlikte yüksek graft kaybı riski devam etmektedir. Bu yüzden orak hücre hastalarında uygulanabilen, GVHH riski azaltılmış ve graft kaybının engellenebildiği yeni rejimlerin geliştirilmesi gereklidir.

Anahtar Sözcükler: Orak hücre hastalığı, Hematopoietik kök hücre nakli, Graft-versus-host hastalığı, Graft kaybı, Hazırlama rejimi

Address for Correspondence: Hakan ÖZDOĞU, M.D.

Başkent University Faculty of Medicine, Department of Internal Medicine, Division of Hematology, Adana, Turkey

Phone: +90 32232727 27-2024 E-mail: hakanozdogu@hotmail.com 


\section{Introduction}

\section{Disease Overview}

Sickle cell disease (SCD) is a homozygous hemoglobin $S$ disease characterized by chronic anemia and tissue injury. Annually, approximately 300,000 babies are born with SCD worldwide. One in every 600 African-Americans in the United States is affected by the disease [1]. Central to the pathogenesis of SCD is a mutation leading to abnormal polymerization of hemoglobin and formation of the characteristic sickle shape as a response to deoxygenation [2,3]. Microvascular ischemia and endothelial activation are responsible for tissue injury.

To date, drug therapy for SCD is limited to fetal hemoglobinstimulating medicines and nonnarcotic and narcotic agents. Use of antisickling agents is not standard, while experience with gene therapy is insufficient. Allogeneic stem cell transplantation is a curative intervention, but it carries a high risk of morbidity and mortality. The development of transplant techniques seems to give better results. In this review, we aim to highlight questions related to transplantation procedures and to discuss our proposals.

\section{Current Reasons for Transplantation}

Current reasons for accepting the risk of transplantation are summarized below. First, the clinical manifestations and complications are dramatic in SCD patients. Second, despite their high costs, no treatment protocol is for protecting from complications. Third, transplantation techniques and patient care have evolved over time.

\section{Manifestations and Complications of Sickle Cell Disease}

SCD is characterized by hemolytic anemia, painful vaso-occlusive crisis, stroke, avascular necrosis, pulmonary hypertension, susceptibility to infections, renal failure, and thrombosis. Consequently, life expectancy is decreased. Neurologic complications develop in $27 \%$ of children with SCD and acute chest syndrome in 25\% [4,5]. These tissue injuries significantly influence quality of life in most patients.

\section{Frontline Treatment Options and Disease Course}

The current, treatment modalities for SCD include fluid replacement, pain control using opioids and analgesics during vaso-occlusive crises, oral hydroxyurea, transfusion, and chelating therapy. Hydroxyurea is effective for reducing the frequency of painful crises and recommended for adults with recurrent episodes of acute chest syndrome [6,7]. Maintaining sickle hemoglobin levels of less than $30 \%$ by transfusion may prevent or control adverse events associated with SCD $[8,9]$. However, these complications may develop despite hydroxyurea use and regular blood transfusions [4,5]. Painful ischemic episodes lead to irreversible sequelae by affecting bones, joints, muscles, and the heart, intestines, kidneys, and eyes. Mean survival is 40 years in developed countries despite advanced supportive care [10]. At our institute, the mean age of patients who died within the last 10 years was 30 years (unpublished data).

\section{Cost}

The disease also has high treatment costs. A study using data from the Florida Medicaid program showed a healthcare cost per patient per month of $\$ 1389$, with significant increases in SCD-related costs from $\$ 892$ in the 0-9-years cohort to $\$ 2562$ in the 50-64-years cohort [11]. The cost of chronic transfusions and chelating therapy alone is $\$ 40,000$ per patient per year in the United States [12,13].

\section{Allogeneic Stem Cell Transplantation}

Hematopoietic stem cell transplantation (HSCT) is a unique curative therapeutic approach in SCD $[14,15,16]$. HSCT may improve central nervous system (CNS), pulmonary system, and pain symptoms by stabilizing organ functions $[17,18]$. Overall survival was reported to be $90 \%$, disease-free survival $82 \%-100 \%$, graft rejection $8 \%-18 \%$, and transplant-related mortality (TRM) 4\%-14\% in transplantations performed mainly with myeloablative conditioning regimens with fully HLA-matched donors in various countries [15,19,20,21,22]. However, this curative treatment approach has some limitations, such as difficulties to find donors, TRM, graft loss, graft-versus-host disease (GVHD), and infertility.

\section{Indications for Transplantation}

Problem: Although HSCT has a curative potential in this nonmalignant disease, it is difficult to determine in which patients the risk of the procedure is acceptable.

\section{Current HSCT indications are summarized in Table 1.}

Extreme variation in the clinical phenotypes of SCD patients makes it difficult to predict the course of the transplantation procedure. However, certain clinical and laboratory factors may predict transplant-associated problems. These factors are renal insufficiency, age $>16$ years, hepatic function abnormalities, and high inflammation [5,17,22,23,24]. In addition, alloantibodies against erythrocytes and HLA antigens and excess iron load develop due to transfusions in the vast majority of patients [25]. Transcranial Doppler ultrasound was shown to be effective for determining the severity of the disease and stroke risk in children. Starting blood transfusion therapy early reduces the risk [26]. Unfortunately, no reliable method is available to predict which patients would develop stroke.

On the other hand, hydroxyurea reduces the frequency and severity of vaso-occlusive crises and acute chest syndrome crises. However, organ injuries continue to occur despite hydroxyurea and current supportive therapies, and mean survival of patients is about 40 years [4,27]. The presence of organ injuries is associated with increased mortality and morbidity. 
Table 1. Indications for hematopoietic stem cell transplantation.

Indications for HSCT (patients $\leq 16$ years)

Stroke or transient CNS event

Silent stroke with cognitive impairment

MRI imaging changes of brain parenchymal damage

MRI angiogram evidence of cerebrovascular disease

Recurrent vaso-occlusive pain crises ( $\geq 2$ per year for the last 2 years), requiring hospitalizations

ACS requiring recurrent hospitalizations

Osteonecrosis of multiple joints

ACS requiring recurrent hospitalizations

Elevated TCD

Red cell alloimmunization ( $\geq 2$ antibodies)

\section{Indications for HSCT (patients $\geq 16$ years)}

Stroke

MRI imaging changes of brain parenchymal damage

MRI angiogram evidence of cerebrovascular disease

ACS requiring exchange transfusion or hospitalization

Recurrent vaso-occlusive pain crises ( $\geq 2$ per year for the last 2

years), requiring hospitalizations

Osteonecrosis of multiple joints

Stage I or II sickle lung disease

Pulmonary hypertension

Sickle hepatopathy (including iron overload)

Sickle-related renal insufficiency ( $C R \geq 1.5$ times the upper limit of normal or biopsy-proven )

Elevated TRV of $\geq 2.6 \mathrm{~m} / \mathrm{s}$

Sickle retinopathy

Red cell alloimmunization ( $\geq 2$ antibodies)

Recurrent priapism

HSCT: Hematopoietic stem cell transplantation, ACS: acute chest syndrome, MRI: magnetic resonance imaging, TCD: transcranial doppler, TRV: tricuspid regurgitant velocity.

Table 2. Transplantations for sickle cell disease by donor type and overall survival according to European Society for Blood and Marrow Transplantation-Eurocord and Center for International Blood and Marrow Transplant Research.

\begin{tabular}{l|l|l|}
\hline & EBMT-Eurocord & CIBMTR \\
\hline $\begin{array}{l}\text { Transplantations for } \\
\text { SCD }\end{array}$ & 611 & 627 \\
\hline $\begin{array}{l}\text { Total } \\
\text { Type of donor }\end{array}$ & \\
\hline $\begin{array}{l}\text { HLA-identical } \\
\text { Cord blood, related } \\
\text { and unrelated }\end{array}$ & 737 & 430 \\
\hline $\begin{array}{l}\text { Haploidentical donor } \\
\text { Other unrelated } \\
\text { donor }\end{array}$ & 34 & 71 \\
\hline
\end{tabular}

SCD: Sickle cell disease, CIBMTR: Center for International Blood and Marrow Transplant Research, EBMT: European Society for Blood and Marrow Transplantation.

Proposed solution: Adult SCD patients have generally been excluded from myeloablative bone marrow transplantation trials because of anticipated excess morbidity and mortality resulting from accumulated disease-related end-organ damage. Rational thought requires applying a curative treatment (i.e. HSCT) in the early period before organ injuries that significantly reduce the life span develop.

\section{Donor}

Problem: The likelihood of finding an HLA-identical sibling donor is low for SCD patients.

In the United States, the estimated number of homozygous SCD patients is around 70,000-100,000 and the overall number of patients who have indications for transplantation is around 5000-7000. A total of 1200 transplantations for SCD were reported in 1986-2013 according to Center for International Blood and Marrow Transplant Research (CIBMTR) and European Society for Blood and Marrow Transplantation (EBMT) records. These rates may be stated to be much lower than needed and expected (Table 2). In a study by Hsieh et al., 24 out of 112 adult patients (21\%) had suitable donors for transplantation. However, the procedure could only be performed in 10 patients (8.9\%) [28].

The vast majority of healthy HLA-identical sibling donors are hemoglobin $\mathrm{S}$ carriers. Although there is evidence that peripheral stem cell mobilization with G-CSF is safe in 
hemoglobin $S$ carrier donors, it should be remembered that G-CSF administration could lead to severe and sometimes fatal sickle cell crisis in carrier donors [29,30,31]. Multiorgan failure was reported in 2 from 11 cases and in 1 case it was fatal. Four people who developed complications required hospitalization. Multiorgan failure and sickle cell crisis were reported to be independent of leukocyte count and G-CSF dose $(2.5-10 \mu \mathrm{g} / \mathrm{kg} / \mathrm{day})$, but they seem to be associated with hemoglobin S concentration [29,30,31]. Erythrocyte exchange or erythrocyte transfusion may be required to reduce the level to $<30 \%$ prior to mobilization. However, there are no data for plerixafor mobilization in hemoglobin $S$ carrier donors. Theoretically, plerixafor might be safer than G-CSF for mobilization as it does not trigger hyperleukocytosis and bone marrow hyperplasia [32].

Severe pain may begin $1 \mathrm{~h}$ after apheresis without mobilization due to transfusion of the erythrocytes, which wait hypoxically in the pulley of the apheresis device. Bone marrow harvesting is safe under local or general anesthesia with careful perioperative management. However, the difficulty in collecting an adequate amount of stem cells for an adult should be remembered. On the other hand, no technical difficulties for cryopreservation were reported in sickle cell carriers who could easily tolerate the procedure $[28,29,30,31,33]$.

Proposed solution: Due to the abovementioned problems, donors who are not carriers should preferably be selected in the interest of donor safety. The hemoglobin $S$ level should be decreased to $<30 \%$ if the donor is a carrier. Bone marrow should be harvested, if possible. Plerixafor should be preferred for mobilization of carrier donors and the rinse-back procedure should be avoided in apheresis procedures.

Overall, less than 25\% of SCD patients have a healthy HLAidentical relative donor. HLA-identical unrelated donors can be found for only a small proportion of patients [34]. A trial of unrelated cord blood transplantation (CBT) was terminated early due to high risks of rejection and GVHD [35]. On the other hand, almost all patients have a haploidentical relative donor. Bolanos-Meade et al. showed that no patients who underwent mismatched transplantation using cyclophosphamide developed GVHD or severe immunodeficiency complications [36]. However, the risk of graft rejection is high in these patients as they are immunocompetent and have proliferative bone marrow. Conditioning regimens are designed to give a low GVHD risk. This problem may be overcome by further developing conditioning regimens (see conditioning regimens below).

\section{Stem Cell Source}

Problem: The ideal stem cell source is not known.

Bone marrow: Bone marrow should be the preferred as the stem cell source due to the low risk of chronic GVHD
(cGVHD). However, HLA-matched donors can be found for only a small proportion of patients. G-CSF-mobilized marrow has been used in the haploidentical (family donor) setting. The use of G-CSF-primed bone marrow grafts to reduce graft loss has been reported [36]. The difficulty in collecting a sufficient amount of stem cells in adults should be considered. In addition, there is evidence that donors of African origin have lower blood counts and reduced numbers of marrow progenitor cells [37].

Haploidentical bone marrow transplantation with posttransplant cyclophosphamide has been applied in patients with hematological malignancies for several years. The Johns Hopkins Group reported that this approach is a feasible and effective treatment with acceptable toxicity [38]. Evidence on the potential use of bone marrow from haploidentical related donors has increased in patients with SCD. BolanosMeade et al. reported promising results with haploidentical nonmyeloablative bone marrow transplantation. They reported durable engraftment and acceptable toxicity with no morbidity and mortality in their series [36].

Peripheral stem cells: They can easily be collected without general anesthesia in the outpatient setting. Their application is less traumatic and has advantages such as less need for transfusion, faster engraftment, less need for platelet suspension, and shorter hospital stays. Although peripheral stem cell products with a 10-fold higher T-cell count increase the risk of cGVHD, their engraftment-facilitating effect should be considered.

Cord blood: This stem cell source has some limitations, such as difficulty to find an HLA-identical donor, GVHD, and graft rejection, despite data showing successful treatment of patients by CBT. A study from the Eurocord Cooperative Group, analyzing the outcome in 44 patients who had SCD or thalassemia major and were treated by CBT with a sibling donor, reported no fatal transplantation-related complications, suggesting that CBT with a related donor is a safe treatment for hemoglobin disorders [38]. However, CBT with matched unrelated donors will likely not be applicable to sufficient numbers of SCD patients because of a lack of suitable donors in national and worldwide registries. CBT with mismatched unrelated donors, although more feasible for pediatric patients based on the availability of 4/6 HLA-matched cord blood units, appears to be associated with a greater risk of graft rejection and GVHD on the basis of the limited data available [39]. Drawbacks such as increased rates of graft rejection, the fixed cell dose, delayed immune reconstitution, and TRM have deterred unrelated cord transplantation efforts [39]. Furthermore, CBT for adults will be limited by the necessary total nucleated cell count per kilogram of body weight for engraftment to occur and the difficulty in achieving this goal in adult patients. Double umbilical cord blood allogeneic 
transplantation with reduced-intensity conditioning is increasingly used in adults lacking a suitable related or unrelated donor [40]. However, the studies of expanded and double cord blood are inadequate.

Proposed solution: Current data indicate that peripheral stem cells mobilized with G-CSF could be a suitable stem cell source for patients with SCD [32]. If the donor is a carrier, decreasing hemoglobin $\mathrm{S}$ level below 30\% of total hemoglobin concentration might be recommended for a safer mobilization process and apheresis procedure. Hematopoietic and lymphoid reconstruction is rapidly achieved through replacement of $\mathrm{T}$ cells by donor peripheral stem cells. Bone marrow from haploidentical donors might be an alternative to matched related or unrelated donors, but this needs more research [40]. Mesenchymal stem cell co-infusion may be considered to prevent GVHD and/or cGVHD and graft loss $[41,42,43]$.

\section{Conditioning Regimens}

Problem: Engraftment efficacy and toxicity for transplantation performed with nonmyeloablative reduced-intensity conditioning regimens are currently being investigated in phase I/II trials at many centers. Preliminary data indicate that GVHD could be prevented by nonmyeloablative reduced-intensity regimens. However, the risk of graft loss remains high.

Allogeneic bone marrow transplantation performed with an HLA-matched donor using a myeloablative-conditioning regimen can cure symptomatic children with SCD. The cure rate was reported to be $85 \%$, the rate of TRM $7 \%$, and the rate of graft rejection $8 \%$ in studies including approximately 200 patients $[16,38,44]$. The results were improved by adding ATG to the conditioning regimen, which gave a cure rate of 95\% (Table 3) [45]. Adult SCD patients have to be excluded from most studies using ablative regimens due to end-organ injury-related morbidity and mortality in most patients, despite positive results in childhood.

Table 3. Myeloablative hematopoietic stem cell transplantation with matched related donors.

\begin{tabular}{|c|c|c|c|c|c|c|c|}
\hline Reference & $\begin{array}{l}\text { Transplantation } \\
\text { Regimen }\end{array}$ & $\begin{array}{l}\text { Number of } \\
\text { Patients } \\
\text { (age range, } \\
\text { years) }\end{array}$ & $\begin{array}{l}\text { Alive } \\
\text { without } \\
\text { SCD, } \\
\text { n }(\%)\end{array}$ & $\begin{array}{l}\text { Acute } \\
\text { GVHD }\end{array}$ & $\begin{array}{l}\text { Chronic } \\
\text { GVHD }\end{array}$ & $\begin{array}{l}\text { Death } \\
\text { (cause) }\end{array}$ & Comments \\
\hline $\begin{array}{l}\text { Vermylen } \\
\text { et al. [15], } \\
1998\end{array}$ & $\begin{array}{l}\text { Bu } 16 \mathrm{mg} / \mathrm{kg}, \text { Cy } \\
200 \mathrm{mg} / \mathrm{kg} \pm \text { TLI or } \\
\text { ATG, CSA }\end{array}$ & $50(0.3-11)$ & 45 (90) & $\begin{array}{l}10(\text { Gr } 1) \\
9(\text { Gr } 2) \\
1(\text { Gr } \\
3-4)\end{array}$ & $\begin{array}{l}7 \text { limited, } \\
3 \text { extensive }\end{array}$ & $\begin{array}{l}2 \text { (acute } \\
\text { GVHD with } \\
\text { CMV and } \\
\text { Aspergillus; } \\
\text { sudden } \\
\text { death) }\end{array}$ & $\begin{array}{l}\text { At } 5 \text { years after } \\
\text { HSCT, } 6 \text { had } \\
\text { mixed } \\
\text { chimerism (3: } \\
>90 \%, 3: 50 \%- \\
70 \%)\end{array}$ \\
\hline $\begin{array}{l}\text { Walters et } \\
\text { al. [14,20], } \\
1996,2001\end{array}$ & $\begin{array}{l}\text { Bu } 14 \mathrm{mg} / \mathrm{kg}, \text { Cy } \\
200 \mathrm{mg} / \mathrm{kg}, \text { ATG or } \\
\text { alemtuzumab, } \\
\text { MTX, CSA }\end{array}$ & $59(3-16)$ & $50(85$ & $\begin{array}{l}11 \text { (acute } \\
\text { or } \\
\text { chronic } \\
\text { GVHD) }\end{array}$ & $\begin{array}{l}\text { 3, all } \\
\text { GVHD }\end{array}$ & & $\begin{array}{l}\text { At } 3.5 \text { years after } \\
\text { HSCT, } 13 \text { had } \\
\text { mixed } \\
\text { chimerism ( } 8 \\
\text { with 90\%-99\%, } \\
5 \text { with } \\
11 \%-74 \%)\end{array}$ \\
\hline $\begin{array}{l}\text { Brachet et } \\
\text { al. [19], } \\
2004\end{array}$ & $\begin{array}{l}\mathrm{Bu} 14-16 \mathrm{mg} / \mathrm{kg}, \\
\text { Cy } 200 \mathrm{mg} / \mathrm{kg} \pm \\
\text { ATG, MTX, CSA }\end{array}$ & $24(2-14)$ & $19(79)$ & $\begin{array}{l}3(\text { Gr } 2) \\
3(\text { Gr } 3)\end{array}$ & 7 limited & $\begin{array}{l}1 \\
\text { (unknown) }\end{array}$ & $\begin{array}{l}\text { At } 8.7 \text { years after } \\
\text { HSCT, } 1 \text { had } \\
\text { mixed } \\
\text { chimerism }\end{array}$ \\
\hline $\begin{array}{l}\text { Bernaudin } \\
\text { et al. [16], } \\
2007\end{array}$ & $\begin{array}{l}\mathrm{Bu} 16 \mathrm{mg} / \mathrm{kg}, \mathrm{Cy} \\
200 \mathrm{mg} / \mathrm{kg} \pm \mathrm{ATG} \\
\mathrm{CSA} \pm \mathrm{MTX}\end{array}$ & $87(2-22)$ & $80(92)$ & $\begin{array}{l}10(\text { Gr } 2) \\
5(\text { Gr } 3) \\
2(\text { Gr } 4)\end{array}$ & $\begin{array}{l}9 \text { limited, } \\
2 \text { extensive }\end{array}$ & $\begin{array}{l}6 \text { (sepsis, } \\
\text { CNS } \\
\text { hemorrhage, } \\
\text { and GVHD } \\
\text { in 4) }\end{array}$ & $\begin{array}{l}\text { At } 6 \text { years after } \\
\text { HSCT, } 25 \%-40 \% \\
\text { had mixed } \\
\text { chimerism } \\
(5 \%-95 \%)\end{array}$ \\
\hline
\end{tabular}

ATG: Antithymocyte globulin, Bu: busulfan, CSA: cyclosporine A, Cy: cyclophosphamide, Gr: grade, MTX: methotrexate, SCD: sickle cell disease, GVHD: graft-versus-host disease. 
In the past, nonmyeloablative bone marrow transplantation strategies developed to cure SCD patients with organ dysfunction gave disappointing results [46,47]. Transplantations done with nonmyeloablative regimens were not as successful as myeloablative transplantations. The main reasons for this included the recipient's not being fully immunocompetent, having proliferative bone marrow, and lack of a GVHD effect. Recently, inconsistently with previous studies, several small patient series have shown promising results $[28,36,48,49]$. Therefore, HSCT following a reducedintensity conditioning nonmyeloablative regimen emerged as a potential treatment option (Table 4 ).

Table 4. Hematopoietic stem cell transplantation from matched related donors with nonmyeloablative conditioning.

\begin{tabular}{|c|c|c|c|c|c|c|c|}
\hline Reference & $\begin{array}{l}\text { Transplant } \\
\text { Regimen }\end{array}$ & $\begin{array}{l}\text { Number of } \\
\text { Patients (age } \\
\text { range, years) }\end{array}$ & $\begin{array}{l}\text { Alive } \\
\text { without } \\
\text { SCD }\end{array}$ & $\begin{array}{l}\text { Acute } \\
\text { GVHD }\end{array}$ & $\begin{array}{l}\text { Chron- } \\
\text { ic GVHD }\end{array}$ & $\begin{array}{l}\text { Death } \\
\text { (cause) }\end{array}$ & Comments \\
\hline $\begin{array}{l}\text { Bolanos- } \\
\text { Meade et al. } \\
{[36], 2012}\end{array}$ & $\begin{array}{l}\text { TBI } 200 \text { cGy, } \\
\text { Flu } 150 \mathrm{mg} / \mathrm{kg}, \\
\text { Cy } 14.5 \mathrm{mg} / \\
\mathrm{kg}, \text { ATG } 4.5 \\
\mathrm{mg} / \mathrm{kg}, \text { post TX } \\
\text { Cy } 100 \mathrm{mg} / \mathrm{kg}, \\
\text { tacrolimus or } \\
\text { sirolimus }\end{array}$ & $17(15-46)$ & 17 & 0 & $\begin{array}{l}1 \text { limited } \\
\text { (skin) }\end{array}$ & 0 & $\begin{array}{l}14 \text { haploidentical } \\
\text { related donors, in } 6 \\
\text { patients graft rejected; } \\
3 \text { matched sibling } \\
\text { donors, no grafts } \\
\text { rejected }\end{array}$ \\
\hline $\begin{array}{l}\text { Hsieh et al. } \\
\text { [28], } 2009\end{array}$ & $\begin{array}{l}\text { TBI } 300 \text { cGy, } \\
\text { alemtuzumab } \\
1 \mathrm{mg} / \mathrm{kg} \text {, } \\
\text { sirolimus }\end{array}$ & $10(16-45)$ & 9 & 0 & 0 & 0 & $\begin{array}{l}\text { At } 3 \text { years after HSCT, } \\
\text { mixed chimerism in } \\
\text { all }\end{array}$ \\
\hline $\begin{array}{l}\text { Hsieh et al. } \\
\text { [49], } 2014\end{array}$ & $\begin{array}{l}\text { TBI } 300 \text { cGy, } \\
\text { alemtuzumab } \\
1 \mathrm{mg} / \mathrm{kg}, \\
\text { sirolimus }\end{array}$ & $30(16-65)$ & 26 & 0 & 0 & $\begin{array}{l}1 \\
\text { (GVHD) }\end{array}$ & $\begin{array}{l}\text { At median } 3.4 \\
\text { years } 15 \text { patients } \\
\text { discontinued } \\
\text { immunosuppression } \\
\text { medication }\end{array}$ \\
\hline $\begin{array}{l}\text { Krishnamurti } \\
\text { et al. [48], } \\
2008\end{array}$ & $\begin{array}{l}\text { BU } 6.4 \mathrm{mg} / \mathrm{kg} \\
\text { IV or } 8 \mathrm{mg} / \mathrm{kg} \\
\text { PO, FLU } \\
175 \mathrm{mg} / \mathrm{kg}, \\
\text { ATG, } 500 \mathrm{cGy} \\
\text { of TLI, CSA, } \\
\text { MMF }\end{array}$ & $7(6-16)$ & 6 & $\begin{array}{l}1 \text { (Gr 2, } \\
\text { skin) }\end{array}$ & $\begin{array}{l}1 \text { limited } \\
\text { (skin) }\end{array}$ & 0 & Mixed chimerism in 4 \\
\hline $\begin{array}{l}\text { Jacobsohn et } \\
\text { al. [46], } 2004\end{array}$ & $\begin{array}{l}\text { BU } 6.4 \mathrm{mg} / \mathrm{kg} \\
\mathrm{IV}, \text { FLU } 180 \\
\mathrm{mg} / \mathrm{m}^{2}, \text { ATG, } \\
\text { CSA, MMF }\end{array}$ & $1(22)$ & 0 & $1(\mathrm{Gr} 1)$ & 1 extensive & $\begin{array}{l}1 \\
\text { (GVHD) }\end{array}$ & \\
\hline $\begin{array}{l}\text { Iannone et al. } \\
{[47]} \\
2003\end{array}$ & $\begin{array}{l}\text { TBI } 200 \text { cGy, } \\
\text { FLU } 150 \mathrm{mg} / \\
\mathrm{m}^{2}, \text { CSA or } \\
\text { tacrolimus, } \\
\text { MMF }\end{array}$ & $6(3-20)$ & 0 & $1(\mathrm{Gr} 2)$ & 0 & 0 & $\begin{array}{l}\text { Transient engraftment } \\
\text { in } 5 \text { patients for } 97 \text { - } \\
441 \text { days }\end{array}$ \\
\hline
\end{tabular}

ATG: Antithymocyte globulin, cGy: centigray, CSA: cyclosporine A, Cy: cyclophosphamide, FLU: fludarabine, Gr: grade, IV: intravenous, MMF: mycophenolate mofetil, MTX: methotrexate, PO: per os, SCD: sickle cell disease, TBI: total body irradiation, TLI: total lymphoid irradiation, GVHD: graft-versus-host disease, HSCT: hematopoietic stem cell transplantation. 
In general, small proportions of engrafted donor red cells seem to be sufficient for clinical control of the disease in SCD patients [50]. Hsieh et al. reported that they achieved permanent engraftment in 26/30 patients and that no patients developed acute GVHD (aGVHD) or cGVHD with a nonmyeloablativeconditioning regimen using alemtuzumab (Campath) and low-dose total-body irradiation (TBI). The mean donor T-cell level was $48 \%$ and the myeloid chimerism level was $86 \%$. Fifteen engrafted patients discontinued immunosuppression medication with continued stable donor chimerism and no GVHD [49]. In this study, sirolimus (rapamycin) was selected as the immunosuppressive agent instead of cyclosporine. Differently from calcineurin inhibitors, sirolimus does not block T-cell activation, but it inhibits T-cell proliferation. The activated but nonproliferated $\mathrm{T}$ cells become anergic, resulting in T-cell tolerance. Sirolimus accelerates the differentiation of regulatory and helper $\mathrm{T}$ cells and this plays a key role in immune tolerance development. Additionally, the renal toxicity of sirolimus is less than that of cyclosporine. Luznik et al. showed that high-dose cyclophosphamide given in the early posttransplantation period could lead to immune tolerance by killing proliferative alloreactive $\mathrm{T}$ cells and preserving nonreactive T cells. High-dose cyclophosphamide is highly toxic to lymphocytes, but hematopoietic stem cells are not affected as they are rich in the aldehyde dehydrogenase enzyme that metabolizes the drug. Posttransplantation highdose cyclophosphamide deletes alloreactive $\mathrm{T}$ cells without affecting nonreactive $\mathrm{T}$ cells or hematopoietic stem cells, thereby reducing the risk of GVHD and enabling immune reconstitution [38]. Bolanos-Meade et al. achieved bone marrow transplantation in adult SCD patients with 14 haploidentical relative donors and 3 matched sibling donors using a nonmyeloablative-conditioning regimen containing cyclophosphamide, ATG, fludarabine, TBI (200 cGy), and posttransplantation high-dose cyclophosphamide [36].

Proposed solution: Novel regimens to reduce GVHD risk and toxicity and prevent graft loss in SCD patients need to be developed. Such regimens may include the following:

ATG-Fresenius: The drug used in preliminary studies is referred to as ATG-thymoglobulin (rabbit) in the literature and its half-life is about $12 \mathrm{~h}$. ATG-Fresenius (rabbit) has a longer half-life (4-10 days) and would provide a significant advantage for preventing graft loss and GVHD.

Busulfex (busulfan): Added to conditioning regimens at microablative doses considering organ injuries. It would open spaces in the bone marrow and help to prevent graft loss.

Treosulfan: Used safely and effectively instead of busulfan in nonmyeloablative regimens in thalassemia patients due to its lower toxicity [51]. However, there is no experience of its use in SCD.
Fludarabine: Used in nonmyeloablative-conditioning regimens in pediatric and adult SCD patients with tissue injuries [52].

Sirolimus: An immunosuppressive agent with an immunotolerogenic effect [53]. It is superior to cyclosporine for providing engraftment without GVHD and reducing posterior reversible encephalopathy syndrome incidence $[28,49]$.

Posttransplantation cyclophosphamide: Posttransplantation high-dose cyclophosphamide, which is successfully used in haploidentical transplantations, should be included in the conditioning regimen. This approach was first described by Luznik et al. Interestingly, while cyclophosphamide given in the early posttransplantation period kills proliferative alloreactive $\mathrm{T}$ cells, it preserves resting nonreactive $\mathrm{T}$ cells. Thus, immune tolerance occurs, GVHD is prevented, T-cell reconstitution is achieved in a short time, and the infection risk decreases [36]. As positive results were obtained in transplantations with HLA-unmatched donors in previous studies, it would also enable haploidentical transplantations. The donor pool would be larger and patients without fully matched donors would have a chance of being cured.

Pretransplantation immune suppression: Administration of 2 cycles of dexamethasone $\left(25 \mathrm{mg} / \mathrm{m}^{2} /\right.$ day for 5 days) to suppress T-cell functions, facilitate engraftment, decrease the GVHD risk, and facilitate the control of disease-related inflammation [54].

Peri- and posttransplantation low-dose steroid administration: Is included in haploidentical protocols and would decrease potential immunologic events (GVHD, graft loss, etc.) by suppressing inflammatory cytokines (TNF- $\alpha$, IL2 , and IL-6) in SCD, which is an inflammatory disease [55].

An adult patient who underwent peripheral stem cell transplantation with a conditioning regimen designed in accordance with the principles recommended above showed no transplant-related adverse events during 20 months following transplantation [56]. Another SCD patient who underwent peripheral stem cell transplantation reached day 10 months following transplantation and is being followed with no complications (unpublished data).

\section{Late Complications}

Problem: Development of late complications.

Patients with SCD are susceptible to common transplantrelated late complications such as infertility, primary gonadal failure, primary hypothyroidism, insulin-dependent diabetes mellitus, osteoporosis, and cGVHD. Fertility is affected by multifactorial causes related to the disease and the procedure [57]. On the other hand, the course of SCDrelated complications like stroke, pulmonary hypertension, 
acute chest, nephropathy, and acute vascular necrosis is an unresolved issue for adult patients. The general prediction is that these complications can improve after transplantation. Due to the absence of available data in adult patients, we accessed pediatric data showing long-term hematological improvements after HSCT with sustained engraftment. These data have supported this expectation in most studies $[58,59,60]$. However, if myeloablative regimens are used, data show that SCD-related organ injuries deteriorate after transplantation over time. This was attributed to the toxic effect of drugs $[58,59,60]$.

Proposed solution: Few published studies have evaluated infertility in patients who received a nonmyeloablative regimen. Therefore, semen cryopreservation or ovum/ zygote cryopreservation should be recommended before transplantation. Current studies indicate that other transplantrelated late complications, particularly aGVHD and cGVHD, are within acceptable limits in adults and can be managed by appropriate treatment with L-thyroxin, calcitriol, estrogen, zoledronic acid, etc. $[50,58,59]$. The use of nonmyeloablative reduced-intensity conditioning is mandatory for adult patients. In addition, it may require individualization of the conditioning regimens as discussed above.

Further studies are required in adults for determining whether reduced-intensity conditioning regimens may offer better outcomes after HSCT.

\section{Conclusion}

Although results of HLA-matched sibling HSCT are encouraging, particularly in children, there are many barriers to this curative treatment option. What risk of mortality and GVHD will families accept in the early period of this benign disease? In one study, only $37 \%$ of relatives of patients accepted a $15 \%$ mortality risk; only $13 \%$ accepted a $15 \%$ mortality risk and a $15 \%$ GVHD risk [60].

Only a small proportion of patients may be candidates for transplantation due to the difficulty to find a matched sibling donor, absence of financial or psychosocial support, the family's not accepting HSCT or the physician's not choosing HCST as a treatment option. In one study, only 44 of 315 patients were found to have an HLA-matched sibling donor [61,62]. In addition, the likelihood of finding an unrelated fully matched donor is very low [34]. An unrelated CBT trial was terminated early due to high risks of rejection and GVHD [35]. Studies to enlarge the donor pool are required. The study of posttransplantation high-dose cyclophosphamide by Bolanos-Meade et al. is encouraging in this regard. Severe GVHD and immunodeficiency, which are seen in mismatched transplantation, were not seen in any of their patients [36].
Development of organ injuries in adult patients requires use of low-toxicity nonmyeloablative regimens for transplantation. This approach results in high rates of graft loss with current conditioning regimens. Although return of the disease is acceptable in such cases, it is one of the barriers that affect the success of transplantation.

Gene transfer to autologous hematopoietic stem cells via viral vectors and gene therapies performed via induced pluripotent stem cells might be possible solutions to the difficulties in finding a matched donor and are exciting treatment options [63,64].

\section{Conflict of Interest Statement}

The authors of this paper have no conflicts of interest, including specific financial interests, relationships, or affiliations, relevant to the subject matter or materials included.

\section{References}

1. Rodgers GP, Noguchi CT, Schechter AN. Sickle cell anemia. Sci Am 1994:48-57.

2. Pauling L, Itano HA. Sickle cell anemia, a molecular disease. Science 1949;110:543-548.

3. Ingram VM. Gene mutations in human haemoglobin: the chemical difference between normal and sickle cell haemoglobin. Nature 1957;180:326-328.

4. Powars DR, Chan LS, Hiti A, Ramicone E, Johnson C. Outcome of sickle cell anemia: a 4-decade observational study of 1056 patients. Medicine (Baltimore) 2005;84:363-376.

5. Hulbert ML, McKinstry RC, Lacey JL, Moran CJ, Panepinto JA, Thompson AA, Sarnaik SA, Woods GM, Casella JF, Inusa B, Howard J, Kirkham FJ, Anie KA, Mullin JE, Ichord R, Noetzel M, Yan Y, Rodeghier M, Debaun MR. Silent cerebral infarcts occur despite regular blood transfusion therapy after first strokes in children with sickle cell disease. Blood 2011;117:772-779.

6. Charache S, Terrin ML, Moore RD, Dover GJ, Barton FB, Eckert SV, McMahon RP, Bonds DR. Effect of hydroxyurea on the frequency of painful crises in sickle cell anemia. Investigators of the Multicenter Study of Hydroxyurea in Sickle Cell Anemia. N Engl J Med 1995;332:1317-1322.

7. Moore RD, Charache S, Terrin ML, Barton FB, Ballas SK. Cost-effectiveness of hydroxyurea in sickle cell anemia. Investigators of the Multicenter Study of Hydroxyurea in Sickle Cell Anemia. Am J Hematol 2000;64:26-31.

8. Wayne AS, Kevy SV, Nathan DG. Transfusion management of sickle cell disease. Blood 1993;81:1109-1123.

9. Davies SC, Roberts-Harewood M. Blood transfusion in sickle cell disease. Blood Rev 1997;11:57-71.

10. Lanzkron S, Carroll CP, Haywood C Jr. Mortality rates and age at death from sickle cell disease: U.S. 1979-2005. Public Health Rep 2013;128:110-116. 
11. Kauf TL, Coates TD, Huazhi L, Mody-Patel N, Hartzema AG. The cost of health care for children and adults with sickle cell disease. Am J Hematol 2009;84:323-327.

12. Platt OS, Brambilla DJ, Rosse WF, Milner PF, Castro O, Steinberg MH, Klug PP. Mortality in sickle cell disease. Life expectancy and risk factors for early death. N Engl J Med 1994;330:1639-1644.

13. Wayne AS, Schoenike SE, Pegelow CH. Financial analysis of chronic transfusion for stroke prevention in sickle cell disease. Blood 2000;96:2369-2372.

14. Walters MC, Patience M, Leisenring W, Eckman JR, Scott JP, Mentzer WC, Davies SC, Ohene-Frempong K, Bernaudin F, Matthews DC, Storb R, Sullivan KM. Bone marrow transplantation for sickle cell disease. N Engl J Med 1996;335:369-376.

15. Vermylen C, Cornu G, Ferster A, Brichard B, Ninane J, Ferrant A, Zenebergh A, Maes P, Dhooge C, Benoit Y, Beguin Y, Dresse MF, Sariban E. Haematopoietic stem cell transplantation for sickle cell anaemia: the first 50 patients transplanted in Belgium. Bone Marrow Transplant 1998;22:1-6.

16. Bernaudin F, Socie G, Kuentz M, Chevret S, Duval M, Bertrand Y, Vannier JP, Yakouben K, Thuret I, Bordigoni P, Fischer A, Lutz P, Stephan JL, Dhedin N, Plouvier E, Margueritte G, Bories D, Verlhac S, Esperou H, Coic L, Vernant JP, Gluckman E; SFGM-TC. Long-term results of related myeloablative stem-cell transplantation to cure sickle cell disease. Blood 2007;110:2749-2756.

17. King A, Shenoy S. Evidence-based focused review of the status of hematopoietic stem cell transplantation as treatment of sickle cell disease and thalassemia. Blood 2014;123:3089-3094.

18. Walters MC, Hardy K, Edwards S, Adamkiewicz T, Barkovich J, Bernaudin F, Buchanan GR, Bunin N, Dickerhoff R, Giller R, Haut PR, Horan J, Hsu LL, Kamani N, Levine JE, Margolis D, Ohene-Frempong K, Patience M, Redding-Lallinger R, Roberts IA, Rogers ZR, Sanders JE, Scott JP, Sullivan KM; Multicenter Study of Bone Marrow Transplantation for Sickle Cell Disease. Pulmonary, gonadal, and central nervous system status after bone marrow transplantation for sickle cell disease. Biol Blood Marrow Transplant 2010;16:263-272.

19. Brachet C, Azzi N, Demulder A, Devalck C, Gourdin A, Gulbis B, Klein A, Le PQ, Loop M, Sariban E, Ferster A. Hydroxyurea treatment for sickle cell disease: impact on haematopoietic stem cell transplantation's outcome. Bone Marrow Transplant 2004;33:799-803.

20. Walters MC, Patience M, Leisenring W, Rogers ZR, Aquino VM, Buchanan GR, Roberts IA, Yeager AM, Hsu L, Adamkiewicz T, Kurtzberg J, Vichinsky E, Storer B, Storb R, Sullivan KM; Multicenter Investigation of Bone Marrow Transplantation for
Sickle Cell Disease. Stable mixed hematopoietic chimerism after bone marrow transplantation for sickle cell anemia. Biol Blood Marrow Transplant 2001;7:665-673.

21. Lucarelli G, Gaziev J, Isgrò A, Sodani P, Paciaroni K, Alfieri C, De Angelis G, Marziali M, Simone MD, Gallucci C, Roveda A, Saltarelli F, Torelli F, Andreani M. Allogeneic cellular gene therapy in hemoglobinopathies-evaluation of hematopoietic SCT in sickle cell anemia. Bone Marrow Transplant 2012;47:227-230.

22. Rees DC, Williams TN, Gladwin MT. Sickle-cell disease. Lancet 2010;376:2018-2031.

23. Powars DR, Elliott-Mills DD, Chan L, Niland J, Hiti AL, Opas LM, Johnson C. Chronic renal failure in sickle cell disease: risk factors, clinical course, and mortality. Ann Intern Med 1991;115:614-620.

24. Bakir AA, Hathiwala SC, Ainis H, Hryhorczuk DO, Rhee HL, Levy PS, Dunea G. Prognosis of the nephrotic syndrome in sickle glomerulopathy. A retrospective study. Am J Nephrol 1987; 7:110-115.

25. McPherson ME, Anderson AR, Castillejo MI, Hillyer CD, Bray RA, Gebel HM, Josephson CD. HLA alloimmunization is associated with RBC antibodies in multiply transfused patients with sickle cell disease. Pediatr Blood Cancer 2010;54:552558.

26. Bernaudin F, Verlhac S, Arnaud C, Kamdem A, Chevret S, Hau I, Coïc L, Leveillé E, Lemarchand E, Lesprit E, Abadie I, Medejel N, Madhi F, Lemerle S, Biscardi S, Bardakdjian J, Galactéros F, Torres M, Kuentz M, Ferry C, Socié G, Reinert P, Delacourt C. Impact of early transcranial Doppler screening and intensive therapy on cerebral vasculopathy outcome in a newborn sickle cell anemia cohort. Blood 2011;117:11301140.

27. Fitzhugh CD, Lauder N, Jonassaint JC, Telen M, Zhao X, Wright EC, Gilliam FR, De Castro LM. Cardiopulmonary complications leading to premature deaths in adult patients with sickle cell disease. Am J Hematol 2010;85:36-40.

28. Hsieh MM, Kang EM, Fitzhugh CD, Link MB, Bolan CD, Kurlander R, Childs RW, Rodgers GP, Powell JD, Tisdale JF. Allogeneic hematopoietic stem cell transplantation for sickle cell disease. N Engl J Med 2009;361:2309-2317.

29. Kang EM, Areman EM, David-Ocampo V, Fitzhugh C, Link ME, Read EJ, Leitman SF, Rodgers GP, Tisdale JF. Mobilization, collection, and processing of peripheral blood stem cells in individuals with sickle cell trait. Blood 2002;99:850-855.

30. Adler BK, Salzman DE, Carabasi MH, Vaughan WP, Reddy VV, Prchal JT. Fatal sickle cell crisis after granulocyte colonystimulating factor administration. Blood 2001;97:3313-3314.

31. Grigg AP. Granulocyte colony-stimulating factor induced sickle cell crisis and multiorgan dysfunction in a patient with compound heterozygous sickle cell/beta+ thalassemia. Blood 2001;97:3998-3999. 
32. Fitzhugh CD, Hsieh MM, Bolan CD, Saenz C, Tisdale JF. Granulocyte colony-stimulating factor (G-CSF) administration in individuals with sickle cell disease: time for a moratorium? Cytotherapy 2009;11:464-471.

33. Sanford K, Roseff SD, Anderson J, Chung HM, McPherson RA. Harvesting autologous stem cells from a patient with red blood cell abnormalities of $\beta$-thalassemia intermedia. Transfusion 2014;54:1881-1886.

34. Dew A, Collins D, Artz A, Rich E, Stock W, Swanson K, van Besien K. Paucity of HLA identical unrelated donors for African-Americans with hematologic malignancies: the need for new donor options. Biol Blood Marrow Transplant 2008;14:938-941.

35. Kamani NR, Walters MC, Carter S, Aquino V, Brochstein JA, Chaudhury S, Eapen M, Freed BM, Grimley M, Levine JE, Logan B, Moore T, Panepinto J, Parikh S, Pulsipher MA, Sande J, Schultz KR, Spellman S, Shenoy S. Unrelated donor cord blood transplantation for children with severe sickle cell disease: results of one cohort from the phase II study from the Blood and Marrow Transplant Clinical Trials Network (BMT CTN). Biol Blood Marrow Transplant 2012;18:1265-1272.

36. Bolanos-Meade J, Fuchs EJ, Luznik L, Lanzkron SM, Gamper CJ, Jones RJ, Brodsky RA. HLA haploidentical bone marrow transplantation with posttransplant cyclophosphamide expands the donor pool for patients with sickle cell disease. Blood 2012;120:4285-4291.

37. Rezvani K, Flanagan AM, Sarma U, Constantinovici N, Bain BJ. Investigation of ethnic neutropenia by assessment of bone marrow colony forming cells. Acta Haematol 2001;105:3237.

38. Luznik L, Fuchs EJ. High-dose, post-transplantation cyclophosphamide to promote graft-host tolerance after allogeneic hematopoietic stem cell transplantation. Immunol Res 2010;47:65-77.

39. Locatelli F, Kabbara N, Ruggeri A, Ghavamzadeh A, Roberts I, Li CK, Bernaudin F, Vermylen C, Dalle JH, Stein J, Wynn R, Cordonnier C, Pinto F, Angelucci E, Socié G, Gluckman E, Walters MC, Rocha V; Eurocord and European Blood and Marrow Transplantation (EBMT) group. Outcome of patients with hemoglobinopathies given either cord blood or bone marrow transplantation from an HLA-identical sibling. Blood 2013;122:1072-1078.

40. Shenoy S. Umbilical cord blood: an evolving stem cell source for sickle cell disease transplants. Stem Cells Transl Med 2013;2:337-340.
41. Peterlin P, Delaunay J, Guillaume T, Gastinne T, Mahé B, Dubruille V, Blin N, Le Bourgeois A, Brissot E, Lodé L, Le Gouill S, Moreau P, Mohty M, Chevallier P. Complete donor T cell chimerism predicts lower relapse incidence after standard double umbilical cord blood reduced intensity conditioning regimen allogeneic transplantation in adults. Biol Blood Marrow Transplant 2015;21:180-184.

42. Fang B, Li N, Song Y, Li J, Zhao RC, Ma Y. Cotransplantation of haploidentical mesenchymal stem cells to enhance engraftment of hematopoietic stem cells and to reduce the risk of graft failure in two children with severe aplastic anemia. Pediatr Transplant 2009;13:499-502.

43. Özdoğu H, Yeral M, Boğa C, Kozanoğlu İ. Use of mesenchymal cells to modulate immune suppression and immune reconstruction in a patient with aplastic anemia complicated by invasive sino-orbital aspergillosis. Turk J Hematol 2014;31:181-183.

44. Walters MC, Patience M, Leisenring W, Eckman JR, Scott JP, Mentzer WC, Davies SC, Ohene-Frempong K, Bernaudin F, Matthews DC, Storb R, Sullivan KM. Bone marrow transplantation for sickle cell disease. N Engl J Med 1996;335:369-376.

45. Bernaudin F, Robin M, Ferry C, Yacouben K, Dalle JH, Peffault de Latour R, Bertrand Y, Pondarre C, Kuentz M, Vannier JP, Fischer A, Thuret I, Lutz P, Bordigoni P, Rohrlich P, Stephan JL, Dhedin N, Vernant JP, Cahn JY, Demeocq F, Rio B, Bories D, Gluckman E, Socié G. Related myeloablative stem cell transplantation (SCT) to cure sickle cell anemia (SCA): update of French results. Blood 2010;116:3518.

46. Jacobsohn DA, Duerst R, Tse W, Kletzel M. Reduced intensity haemopoietic stem-cell transplantation for treatment of nonmalignant diseases in children. Lancet 2004;364:156-162.

47. Iannone R, Casella JF, Fuchs EJ, Chen AR, Jones RJ, Woolfrey A, Amylon M, Sullivan KM, Storb RF, Walters MC. Results of minimally toxic nonmyeloablative transplantation in patients with sickle cell anemia and beta thalassemia. Biol Blood Marrow Transplant 2003;9:519-528.

48. Krishnamurti L, Kharbanda S, Biernacki MA, Zhang W, Baker KS, Wagner JE, Wu CJ. Stable long-term donor engraftment following reduced-intensity hematopoietic cell transplantation for sickle cell disease. Biol Blood Marrow Transplant 2008;14:1270-1278.

49. Hsieh MM, Fitzhugh CD, Weitzel RP, Link ME, Coles WA, Zhao x, Rodgers GP, Powell JD, Tisdale JF. Nonmyeloablative HLA-matched sibling allogeneic hematopoietic stem cell transplantation for severe sickle cell phenotype. JAMA 2014;312:48-56. 
50. Hsieh MM, Wu CJ, Tisdale JF. In mixed hematopoietic chimerism, the donor red cells win. Haematologica 2011;96:13-15.

51. Bernardo ME, Piras E, Vacca A, Giorgiani G, Zecca M, Bertaina A, Pagliara D, Contoli B, Pinto RM, Caocci G, Mastronuzzi A, La Nasa G, Locatelli F. Allogeneic hematopoietic stem cell transplantation in thalassemia major: results of a reducedtoxicity conditioning regimen based on the use of treosulfan. Blood 2012;120:473-476.

52. Horwitz ME, Spasojevic I, Morris A, Telen M, Essel J, Gasparetto C, Sullivan K, Long G, Chute J, Chao N, Rizzieri D. Fludarabine-based nonmyeloablative stem cell transplantation for sickle cell disease with and without renal failure: clinical outcome and pharmacokinetics. Biol Blood Marrow Transplant 2007;13:1422-1426.

53. Powell JD, Fitzhugh C, Kang M, Hsieh M, Schwartz RH, Tisdale JF. Low-dose radiation plus rapamycin promotes long-term bone marrow chimerism. Transplantation 2005;80:15411545.

54. Anurathapan U, Pakakasama S, Rujkijyanont P, Sirachainan $\mathrm{N}$, Songdej D, Chuansumrit A, Sirireung S, Charoenkwan P, Jetsrisuparb A, Issaragrisil S, Ungkanont A, Sruamsiri R, Srisala S, Andersson BS, Hongeng S. Pretransplant immunosuppression followed by reduced-toxicity conditioning and stem cell transplantation in high-risk thalassemia: a safe approach to disease control. Biol Blood Marrow Transplant 2013;19:1259-1262.

55. Ogawa H, Ikegame K, Kaida K, Yoshihara S, Fujioka T, Taniguchi Y, Tamaki H, Inoue T, Hasei H, Iiboshi Y, Tazuke Y,Kawakami M, Kim EH, Soma T, Inoue T, Kawase I. Unmanipulated HLA 2-3 antigen-mismatched (haploidentical) bone marrow transplantation using only pharmacological GVHD prophylaxis. Exp Hematol 2008;36:1-8.

56. Özdoğu H, Yeral M, Boğa C, Kozanoğlu İ, Maytalman E, Gereklioğlu Ç. Hemopoietic stem cell transplantation for adult patient with sickle cell disease: a case report. Experimental and Clinical Transplantation 2014;12(Suppl):294.

57. Gharwan H, Neary NM, Link M, Hsieh MM, Fitzhugh CD, Sherins RJ, Tisdale JF. Successful fertility restoration after allogeneic hematopoietic stem cell transplantation. Endocr Pract 2014:20:157-161.
58. Dallas MH, Triplett B, Shook DR, Hartford C, Srinivasan A, Laver J, Ware R, Leung W. Long-term outcome and evaluation of organ function in pediatric patients undergoing haploidentical and matched related hematopoietic cell transplantation for sickle cell disease. Biol Blood Marrow Transplant 2013;19:820-830.

59. Sheth S, Licursi M, Bhatia M. Sickle cell disease: time for a closer look at treatment options? Br J Haematol 2013;162:455464.

60. Khalil A, Zaidman I, Elhasid R, Peretz-Nahum M, Futerman $\mathrm{B}$, Ben-Arush M. Factors influencing outcome and incidence of late complications in children who underwent allogeneic hematopoietic stem cell transplantation for hemoglobinopathy. Pediatr Hematol Oncol 2012;29:694-703.

61. Kodish E, Lantos J, Stocking C, Singer PA, Siegler M, Johnson FL. Bone marrow transplantation for sickle cell disease. A study of parents' decisions. N Engl J Med 1991;325:13491353.

62. Walters MC, Patience M, Leisenring W, Eckman JR, Buchanan GR, Rogers ZR, Olivieri NE, Vichinsky E, Davies SC, Mentzer WC, Powars D, Scott JP, Bernaudin F, Ohene-Frempong K, Darbyshire PJ, Wayne A, Roberts IA, Dinndorf P, Brandalise S, Sanders JE, Matthews DC, Appelbaum FR, Storb R, Sullivan $\mathrm{KM}$. Barriers to bone marrow transplantation for sickle cell anemia. Biol Blood Marrow Transplant 1996;2:100-104.

63. Pawliuk R, Westerman KA, Fabry ME, Payen E, Tighe R, Bouhassira EE, Acharya SA, Ellis J, London IM, Eaves CJ, Humphries RK, Beuzard Y, Nagel RL, Leboulch P. Correction of sickle cell disease in transgenic mouse models by gene therapy. Science 2001;294:2368-2371.

64. Sebastiano V, Maeder ML, Angstman JF, Haddad B, Khayter C, Yeo DT, Goodwin MJ, Hawkins JS, Ramirez CL, Batista LF, Artandi SE, Wernig M, Joung JK. In situ genetic correction of the sickle cell anemia mutation in human induced pluripotent stem cells using engineered zinc finger nucleases. Stem Cells 2011;29:1717-1726. 